\title{
The fate of nitrogen fixed by diazotrophs in the ocean
}

\author{
M. R. Mulholland \\ Department of Ocean, Earth and Atmospheric Sciences, Old Dominion University, 4600 Elkhorn Avenue, Norfolk, Virginia \\ 23529-0276, USA
}

Received: 8 May 2006 - Published in Biogeosciences Discuss.: 19 July 2006

Revised: 22 November 2006 - Accepted: 6 December 2006 - Published: 12 January 2007

\begin{abstract}
While we now know that $\mathrm{N}_{2}$ fixation is a significant source of new nitrogen $(\mathrm{N})$ in the marine environment, little is known about the fate of this $\mathrm{N}$ (and associated C), despite the importance of diazotrophs to global carbon and nutrient cycles. Specifically, does $\mathrm{N}$ fixed during $\mathrm{N}_{2}$ fixation fuel autotrophic or heterotrophic growth and thus facilitate carbon (C) export from the euphotic zone, or does it contribute primarily to bacterial productivity and respiration in the euphotic zone? For Trichodesmium, the diazotroph we know the most about, the transfer of recently fixed $\mathrm{N}_{2}$ (and C) appears to be primarily through dissolved pools. The release of $\mathrm{N}$ varies among and within populations and as a result of the changing physiological state of cells and populations. The net result of trophic transfers appears to depend on the co-occurring organisms and the complexity of the colonizing community. In order to understand the impact of diazotrophy on carbon flow and export in marine systems, we need a better understanding of the trophic flow of elements in Trichodesmium-dominated communities and other diazotrophic communities under various defined physiological states. $\mathrm{Ni}$ trogen and carbon fixation rates themselves vary by orders of magnitude within and among studies of Trichodesmium, highlighting the difficulty in extrapolating global rates of $\mathrm{N}_{2}$ fixation from direct measurements. Because the stoichiometry of $\mathrm{N}_{2}$ and $\mathrm{C}$ fixation does not appear to be in balance with that of particles, and the relationship between $\mathrm{C}$ and $\mathrm{N}_{2}$ fixation rates is also variable, it is equally difficult to derive global rates of one from the other. This paper seeks to synthesize what is known about the fate of diazotrophic production in the environment. A better understanding of the physiology and physiological ecology of Trichodesmium and other marine diazotrophs is necessary to quantify and predict the effects of increased or decreased diazotrophy in the context of the carbon cycle and global change.
\end{abstract}

Correspondence to: M. R. Mulholland

(mmulholl@odu.edu)

\section{Introduction}

Although we now know that dinitrogen $\left(\mathrm{N}_{2}\right)$ fixation is a significant source of new nitrogen $(\mathrm{N})$ fueling primary production in the marine environment (sensu Dugdale and Goering, 1967), little is known about the fate of this production, whether it is exported or stimulates remineralization (e.g., Eppley and Peterson, 1979), despite the importance of diazotrophs to global carbon and nutrient cycles (Karl et al., 2002; LaRoche and Breitbarth, 2005). A variety of marine cyanobacteria and bacteria are now known to fix $\mathrm{N}_{2}$ in marine environments, however, Trichodesmium spp. remain the most studied and most quantitatively significant pelagic nitrogen fixer based on available information. Trichodesmium spp. occur throughout the subtropical and tropical ocean where they can represent up to half of the primary production (Carpenter et al., 2004). Based on direct rate measurements, Trichodesmium accounts for a quarter to half of geochemically derived estimates of marine $\mathrm{N}_{2}$ fixation (Mahaffey et al., 2005). In addition to Trichodesmium, pelagic nitrogen fixers include other filamentous cyanobacteria, unicellular cyanobacteria, bacterioplankton, and cyanobacterial endosymbionts (Carpenter et al., 1999; Zehr et al., 2001; Montoya et al., 2004; Carpenter and Capone, 2007).

Global estimates of $\mathrm{N}_{2}$ fixation and possible controls on marine $\mathrm{N}_{2}$ fixation, at least by Trichodesmium, have been recently summarized and reviewed (LaRoche and Breitbarth, 2005; Mahaffey et al., 2005; Carpenter and Capone, 2007) and so will not be re-reviewed here. Growth rates of these organisms vary by orders of magnitude as do rates of $\mathrm{N}_{2}$ and carbon fixation (see Mulholland et al., 2006) and reasons for this variability are not well understood. Inputs of $\mathrm{N}$ and carbon $(\mathrm{C})$ via diazotrophic growth have been measured directly or extrapolated in a variety of systems, however, the quantification of loss terms for $\mathrm{N}$ and $\mathrm{C}$ (e.g., export) are poorly constrained. Trichodesmium are rarely found in sediment traps and are positively buoyant (Walsby, 1992) and so sinking appears to be a minor loss term compared with cell

Published by Copernicus GmbH on behalf of the European Geosciences Union. 
lysis (Ohki, 1999; Hewson et al., 2004), extracellular release (Capone et al., 1994; Glibert and Bronk, 1994; Mulholland et al., 2004a), and grazing (O’Neil et al., 1996; O'Neil, 1999), each of which are discussed below. These observations suggest that material produced by diazotrophs may be primarily recycled in the surface ocean, unless there is another, as-yet unidentified pathway to export surface $\mathrm{N}$ fluxes due to diazotrophy to depth. In this paper, the fate of primary production from diazotrophy will be reviewed based on collected observations (published and not yet published) of $\mathrm{N}_{2}$ fixation and associated carbon fixation rates, $\mathrm{N}$ and $\mathrm{C}$ release, and trophodynamics associated with nutrient cycling.

\section{$2 \mathbf{N}_{2}$ fixation}

Pelagic $\mathrm{N}_{2}$ fixation is an important source of new $\mathrm{N}$ to otherwise oligotrophic marine systems. The most widely studied pelagic marine diazotrophs, Trichodesmium spp., play a pivotal role in marine elemental cycles in otherwise oligotrophic tropical and subtropical seas (Capone et al., 1997; Karl et al., 2002; LaRoche and Breitbarth, 2005). Globally, based on direct measurements, oceanic $\mathrm{N}_{2}$ fixation by Trichodesmium has been estimated to be 60 (Mahaffey et al., 2005) to $80 \mathrm{Tg}$ $\mathrm{N}$ year $^{-1}$ (Capone and Carpenter, 1999), and represents upwards of $50 \%$ of the new production in some oligotrophic tropical and subtropical oceans (Karl et al., 1997; Capone et al., 2005; Mahaffey et al., 2005). Based on observed and derived $\mathrm{N}_{2}$ fixation rates by Trichodesmium, $\mathrm{N}_{2}$ fixation by these species alone is comparable in magnitude to the estimated diffusive nitrate flux across the base of the euphotic zone in tropical and subtropical systems (Karl et al., 1997; Capone, 2001; Capone et al., 2005).

However, Trichodesmium still represent only 40 to $59 \%$ of the geochemically inferred $\mathrm{N}_{2}$ fixation for the North Atlantic and Pacific (Mahaffey et al., 2005). The recent discoveries of diazotrophic unicellular cyanobacteria and bacterioplankton in marine systems (e.g., Zehr et al., 2001; Falcón et al., 2004; Montoya et al., 2004) suggest that there are additional sources of $\mathrm{N}_{2}$ fixation that may yet reconcile measurements with geochemically predicted rates of $\mathrm{N}_{2}$ fixation in the ocean. Although, the full range of diazotrophic marine organisms is as yet, unknown, it is thought that unicellular diazotrophs may contribute up to $10 \%$ of global new production (Montoya et al., 2004). Richelia intracellularis, an endosymbiotic cyanobacterium that can inhabit a diverse group of diatoms, fixes significant amounts of nitrogen where diatom/Richelia associations occur (Carpenter et al., 1999). Based on the available rate measurements and regional and global abundance estimates in the euphotic zone, endosymbiotic and free-living unicellular cyanobacteria and bacteria are now believed to fix at least as much nitrogen as Trichodesmium in the ocean (Table 1; Carpenter et al., 1999; Zehr et al., 2001; Montoya et al., 2004). As a result, recent estimates for total pelagic marine $\mathrm{N}_{2}$ fixation are now be- tween 100 and $200 \mathrm{Tg} \mathrm{N}_{\text {year }}{ }^{-1}$ (Karl et al., 2002; Galloway et al., 2004).

Extrapolation of $\mathrm{N}_{2}$ fixation rates made in laboratory or field populations of Trichodesmium to the world's ocean can yield a wide range of global marine $\mathrm{N}_{2}$ fixation rates. For example, rates of $\mathrm{N}_{2}$ fixation by Trichodesmium from field populations vary by six orders of magnitude (LaRoche and Breitbarth, 2005; Mulholland et al., 2006). Laboratory estimates vary only by about 4 orders of magnitude, but still, which rates do we choose for our global estimate? Based on laboratory studies, rates of $\mathrm{N}_{2}$ fixation vary with environmental factors and according to physiological state (e.g., Mulholland et al. 1999, 2001; Mulholland and Capone, 2001; Mulholland and Bernhardt, 2005; Breitbarth et al., 2006; Hutchins et al., 2007) and yet the physiological state of natural populations is impossible to assess at the time of sampling. It is thought that rates of $\mathrm{N}_{2}$ fixation and growth by Trichodesmium are limited by phosphorus (P), iron (Fe), or light (Sañudo-Wilhelmy et al., 2001; Mills et al., 2004; Fu et al., 2005; Mulholland and Bernhardt, 2005). However, the range of responses to these variables and their interactions is unknown (Mulholland and Bernhardt, 2005).

Besides real physiological variability, rates vary depending on the method used to estimate $\mathrm{N}_{2}$ fixation. The two most commonly used methods are the acetylene reduction method and ${ }^{15} \mathrm{~N}_{2}$ uptake; the former measures gross $\mathrm{N}_{2}$ fixation and the latter measures net $\mathrm{N}_{2}$ uptake into biomass (Gallon et al., 2002; Mulholland et al., 2004, 2006). The acetylene reduction method relies on a conversion factor to convert moles of acetylene to moles $\mathrm{N}_{2}$ reduced and the value of this conversion factor has been a matter of debate (see Capone, 1993; Mulholland et al., 2004, 2006; LaRoche and Breitbarth, 2005). Paired comparisons between the two methods used to calibrate one against the other demonstrate that the ratio between acetylene reduction and $\mathrm{N}_{2}$ uptake varies widely both within and among systems and studies (Table 2). Consequently, we are left with an unsatisfying set of data with which to make direct estimates of global $\mathrm{N}_{2}$ fixation.

In addition to extrapolations from direct measurements of $\mathrm{N}_{2}$ fixation rates, global estimates of marine $\mathrm{N}_{2}$ fixation have been inferred based on geochemical arguments that rely on elemental stoichiometry of particles and dissolved nutrients in the ocean (see Mahaffey et al., 2005, for a more complete discussion). There are limitations to both of these approaches, however, because of methodological constraints and the physiological peculiarities of the dominant marine $\mathrm{N}_{2}$ fixer, Trichodesmium, discussed below. The physiology of more recently identified $\mathrm{N}_{2}$ fixers is still being elucidated and so it is premature to speculate on how these groups may influence estimates of global new production and carbon export. 
Table 1. Ranges of water column $\mathrm{N}_{2}$ fixation rates. Rates are presented as hourly rates because it is unclear whether $\mathrm{N}_{2}$ fixation by unicellular diazotrophs exhibits diel periodicity. For comparison, rates of $\mathrm{N}_{2}$ fixation by Trichodesmium range from $<0.01$ to $2.14 \mathrm{nmol} \mathrm{N}$ col $^{-1} \mathrm{~h}^{-1}$ $\left(\mathrm{N}_{2}\right.$ fixation is confined to the light period) and colony abundance can range from $<1$ to $>1000$ colonies $\mathrm{L}^{-1}$ (Mulholland et al., 2006).

\begin{tabular}{|c|c|c|c|c|c|}
\hline Date & Location & Depth & $\begin{array}{l}\mathrm{N}_{2} \text { fixation } \\
\left(\mathrm{nmol} \mathrm{L}{ }^{-1} \mathrm{~h}^{-1}\right)\end{array}$ & Method & Reference \\
\hline $2001-2003$ & Gulf of Mexico & Surface & $0.011-0.23$ & ${ }^{15} \mathrm{~N}_{2}$ & Mulholland et al. (2006) \\
\hline 2003 & Gulf of Mexico & Pigment maximum & $0.044-0.063$ & ${ }^{15} \mathrm{~N}_{2}$ & Mulholland et al. (2006) \\
\hline 2002 & New Caledonia & Surface & $0.23-0.85$ & ${ }^{15} \mathrm{~N}_{2}$ & Mulholland et al. (2006) \\
\hline 2002 & N Atlantic & $25 \mathrm{~m}$ (nighttime) & $\sim 0.147$ & $\mathrm{AR}$ & Falcon et al. (2004) \\
\hline 2001 & N. Atlantic & Upper $100 \mathrm{~m}$ & $0.025-0.045$ & ${ }^{15} \mathrm{~N}_{2}$ & Falcon et al. (2004) \\
\hline 2002 & N Pacific & Upper 100 m (nighttime) & $\sim 0.003$ & $\mathrm{AR}$ & Falcon et al. (2004) \\
\hline 2000-2001 & $\begin{array}{l}\text { Station ALOHA \& } \\
\text { Kaneohe Bay }\end{array}$ & $25 \mathrm{~m} \&$ Surface & $0.01-0.15$ & ${ }^{15} \mathrm{~N}_{2}$ & Montoya et al. (2004) \\
\hline 2002 & Eastern N. Pacific & Mixed layer \& pigment maximum & $0.047-1.85(0.72)$ & ${ }^{15} \mathrm{~N}_{2}$ & Montoya et al. (2004) \\
\hline 1999 & Arafura Sea & Pigment maximum & $20-62$ & ${ }^{15} \mathrm{~N}_{2}$ & Montoya et al. (2004) \\
\hline 2000 & Station ALOHA & $25 \mathrm{~m}$ & $0.010-0.016$ & ${ }^{15} \mathrm{~N}_{2}$ & Zehr et al. (2001) \\
\hline 2002 & Tropical Atlantic & Upper $100 \mathrm{~m}$ & up to 3.1 & ${ }^{15} \mathrm{~N}_{2}$ & Voss et al. (2004) \\
\hline 2000-2001 & Station ALOHA & Upper $100 \mathrm{~m}$ & $0-0.09$ & ${ }^{15} \mathrm{~N}_{2}$ & Dore et al. $(2002)^{1}$ \\
\hline
\end{tabular}

${ }^{1}$ Converted from daily rate assuming $\mathrm{N}_{2}$ fixation persisted for $24 \mathrm{~h}$ per day.

\section{Carbon fixation}

Global estimates of carbon fixation by marine diazotrophs based on direct measurements have not been attempted to the author's knowledge. There are few published estimates of carbon fixation (compared to $\mathrm{N}_{2}$ fixation) by Trichodesmium and global carbon fixation by this genus is generally estimated by multiplying the nitrogen fixation rate by some average C:N for Trichodesmium biomass. Modeling results assume $\mathrm{N}_{2}$ fixation equals denitrification, which corresponds to $480-960 \mathrm{Tg} \mathrm{C}$ year $^{-1}$ (Mahaffey et al., 2005). Fortunately, the C:N ratio of Trichodesmium biomass, unlike the N:P ratios, falls within a narrow range (4.7 to 7.3; LaRoche and Breitbarth, 2005) with an average value of 6.3, very near the Redfield ratio (6.6). Unfortunately, as for $\mathrm{N}_{2}$ fixation, direct rate measurements of carbon fixation and carbon specific turnover times by Trichodesmium vary by orders of magnitude (Mulholland et al., 2006). Further, there is no consistent stoichiometric relationship between the ratio of $\mathrm{C}$ to $\mathrm{N}_{2}$ fixation (Table 3). Available paired estimates of $\mathrm{N}_{2}$ and $\mathrm{C}$ fixation suggest that in general, C:N fixation ratios far exceed the C:N ratio of cells (see also Mulholland et al., 2006). Consequently, geochemical estimates that rely on elemental stoichiometry to extrapolate $\mathrm{N}_{2}$ fixation from observations of carbon drawdown or the carbon cycle in general may be grossly in error (Mahaffey et al., 2005). For example, at the Bermuda Atlantic Time-Series Study (BATS) site, the observed rates of $\mathrm{C}$ drawdown were much higher than that which can be accounted for based on the observed rates of $\mathrm{N}_{2}$ fixation and Redfield stoichiometry. However, when the average observed ratio of carbon to $\mathrm{N}_{2}$ fixation rates mea- sured at BATS (C: $\mathrm{N}_{2}$ fixation rates of 128) were used, the observed low rates of $\mathrm{N}_{2}$ fixation could indeed account for the observed carbon drawdown at BATS (Orcutt et al., 2001). Interestingly, the extrapolation of $\mathrm{N}_{2}$ fixation rates necessary to close $\mathrm{C}$ budgets may be seriously biased (overestimated) if the actual rate relationships between $\mathrm{N}_{2}$ and carbon fixation are NOT considered. The relationship between $\mathrm{N}$ and $\mathrm{P}$ may be even more complex.

There are a variety of reasons why there may be higherthan-stoichiometrically-expected carbon to $\mathrm{N}_{2}$ fixation ratios in nature. These include: factors resulting in underestimates of $\mathrm{N}_{2}$ fixation rates and rationalizations as to why Trichodesmium may have unusually high carbon fixation rates. Regarding the former, gross $\mathrm{N}_{2}$ fixation rates can be underestimated in ${ }^{15} \mathrm{~N}_{2}$ incubations if there is substantial $\mathrm{N}$ release (Glibert and Bronk, 1994; Mulholland et al., 2004a, 2006; see Sect. 4 below) or gross $\mathrm{N}$ utilization may be underestimated if alternative $\mathrm{N}$ sources are taken up (Mulholland and Capone, 1999; Mulholland et al., 1999a, b). On the other hand, carbon fixation rates may be stoichiometrically higher than expected, based on the elemental ratio of cells, if carbon is used as ballast for vertical migration (Villareal and Carpenter, 1990; Romans et al., 1994; Gallon et al., 1996), if substantial carbon is excreted as mucilage or extracellular polymeric substances (Stal, 1995; Sellner, 1997), to support the high observed respiration rates by Trichodesmium (Kana, 1993; Carpenter and Roenneberg, 1995), or if cells "overfix" carbon to support Mehler reactions to reduce cellular oxygen concentrations or support the production of ATP (Kana, 1992, 1993). Kana (1993) estimated that $48 \%$ of gross photosynthetic electron flow went to oxygen reduction. 
Table 2. Results from paired comparisons of $\mathrm{C}_{2} \mathrm{H}_{2}: \mathrm{N}_{2}$ measurements. Numbers are reported as molar ratios and $\mathrm{N}$ release is estimated as the observed molar ratio minus the theoretical ratio (3) divided by the observed molar ratio.

\begin{tabular}{|c|c|c|c|c|}
\hline \multirow[t]{2}{*}{ Location } & \multicolumn{2}{|c|}{$\mathrm{C}_{2} \mathrm{H}_{2}: \mathrm{N}_{2}$ (molar ratio) } & \multirow{2}{*}{$\begin{array}{l}\text { Average } \mathrm{N} \text { release } \\
\%\end{array}$} & \multirow[t]{2}{*}{ Reference } \\
\hline & Range & Average & & \\
\hline \multicolumn{5}{|l|}{ Trichodesmium: } \\
\hline Gulf of Mexico & $3.3-15.8$ & 7.3 & 52 & Mulholland et al. (2006) \\
\hline $\begin{array}{l}\text { North Atlantic (latitudinal gradient) - } \\
\text { Aug }\end{array}$ & $3.1-7.5$ & 4.6 & 29 & Mulholland et al. (unpublished data) \\
\hline $\begin{array}{l}\text { North Atlantic (latitudinal gradient) - } \\
\text { March }\end{array}$ & $6.3-52.7$ & 28.3 & 79 & Mulholland et al. (unpublished data) \\
\hline North Atlantic & $0.9-7.3$ & 3.6 & 17 & Capone et al. (2005) \\
\hline Sargasso Sea & & 6.0 & 50 & Carpenter and McCarthy (1975) \\
\hline Sargasso Sea & & 6.3 & 52 & Carpenter and Price (1977) \\
\hline Sargasso Sea & & 2.9 & & Scranton (1984) \\
\hline \multicolumn{5}{|l|}{ Sargasso Sea } \\
\hline Caribbean and Sargasso Seas & & 4.1 & 27 & Scranton et al. (1987) \\
\hline Caribbean Sea & & 7.2 & & Carpenter and Price (1977) \\
\hline Caribbean Sea & & 3.4 & 12 & Glibert and Bronk (1994) \\
\hline BATS (net tows) & & 4.9 & 39 & Orcutt et al. (2001) \\
\hline BATS (SCUBA) & & 1.4 & & Orcutt et al. (2001) \\
\hline BATS & & 3.0 & & Orcutt et al. (2001) \\
\hline North Pacific & & 1.9 & & Mague et al. (1977) \\
\hline Bay of Bengal \& South China Sea & $3-10$ & 2.9 & & Saino (1977) \\
\hline New Caledonia lagoon - S. Pacific & $4.8-19.5$ & & $21-97$ & Mulholland et al. (unpublished data) \\
\hline Trichodesmium IMS101 (batch) & $1.7-9.8$ & 5.6 & 46 & Mulholland et al. (2004a) \\
\hline $\begin{array}{l}\text { Trichodesmium IMS101 } \\
\text { (continuous) }\end{array}$ & $3.0-22.2$ & 11.4 & 74 & Mulholland and Bernhardt (2005) \\
\hline $\begin{array}{l}\text { Trichodesmium IMS101 } \\
\text { (semi-continuous) - morning }\end{array}$ & $4.9-14.9$ & 8.9 & 59.7 & Hutchins et al. (2007) \\
\hline $\begin{array}{l}\text { Trichodesmium IMS101 } \\
\text { (semi-continuous) - afternoon }\end{array}$ & $14.3-45.6$ & 23.5 & 81.6 & Hutchins et al. (2007) \\
\hline $\begin{array}{l}\text { Trichodesmium GBRTRLI101 - } \\
\text { afternoon }\end{array}$ & $8.8-24.9$ & 16.7 & 76.5 & Hutchins et al. (2007) \\
\hline \multicolumn{5}{|l|}{ Other marine cyanobacteria: } \\
\hline Rhizosolenia/Richelia association & & 9.3 & & Mague et al. (1974) \\
\hline Mixed cyanobacteria - & & $3.8-20$ & & Gallon et al. (2002) \\
\hline \multicolumn{5}{|l|}{ Nodularia spumigena/Anabaenal } \\
\hline \multicolumn{5}{|l|}{ Aphanizomenon } \\
\hline Aphanizomenon spp. & & 4.7 & & Montoya et al. (1996) \\
\hline
\end{tabular}

Trichodesmium also make poly-beta-hydroxybutyric acid as a storage product (Siddiqui et al., 1992) and this may be important in carbohydrate ballasting (Romans et al., 1994) but would require additional cellular carbon reserves. In addition to these physiological reasons why carbon might be "overfixed" relative to nitrogen, active release of carbon compounds and photosynthate has been observed and will be discussed below in Sect. 5. Alternatively, $\mathrm{N}$ and $\mathrm{C}$ uptake may not be tightly coupled in diazotrophic cyanobacteria (Gallon et al., 2002).

An interesting genomic finding is that Trichodesmium erythraeum is unusual among cyanobacteria in that it lacks any genes encoding known high-affinity carbon concentrat- ing mechanisms (Badger and Price, 2003). While it is not clear how this affects photosynthetic $\mathrm{C}$ acquisition by Trichodesmium, it suggests this species is vulnerable to $\mathrm{C} \mathrm{lim-}$ itation. Continuous carbon fixation or storage of fixed carbon compounds, even in excess of their growth requirements, may protect them from carbon limitation in nature. Although carbon limitation has not been demonstrated for these species in nature, the interiors of Trichodesmium colonies have been shown to exhibit oxygen dynamics that may be important for aerobic $\mathrm{N}_{2}$ fixation (Paerl and Bebout, 1988; Carpenter et al., 1990; Gallon, 1992).

Although the ultimate biogeochemical fate of Trichodesmium-fixed elements is not fully understood 
Table 3. Paired comparisons of $\mathrm{C}$ and $\mathrm{N}_{2}$ fixation.

\begin{tabular}{|c|c|c|c|}
\hline \multirow[t]{2}{*}{ Location } & \multicolumn{2}{|c|}{$\mathrm{C}: \mathrm{N}_{2}$ fixation } & \multirow[t]{2}{*}{ Reference } \\
\hline & Range & Average & \\
\hline \multicolumn{4}{|l|}{ Trichodesmium: } \\
\hline Gulf of Mexico & $5.4-42.7$ & 13.1 & Mulholland et al. (2006) \\
\hline New Caledonia (lagoon) - morning & $3.7-51.3$ & & Mulholland et al. (unpublished data) \\
\hline $\begin{array}{l}\text { North Atlantic (latitudinal gradient) - } \\
\text { Aug }\end{array}$ & $11.0-30.6$ & 20.1 & Mulholland et al. (unpublished data) \\
\hline $\begin{array}{l}\text { North Atlantic (latitudinal gradient) - } \\
\text { March }\end{array}$ & $5.2-22.4$ & 12.8 & Mulholland et al. (unpublished data) \\
\hline North Pacific & $1.2-2.1$ & & Mague et al. (1977) \\
\hline Sargasso Sea & & 16 & Carpenter and Price (1977) \\
\hline Sargasso Sea & $1.5-87$ & & McCarthy and Carpenter (1979) \\
\hline BATS (puffs) & $13-437$ & 128 & Orcutt et al. (2001) \\
\hline BATS (tufts) & $15-703$ & 198 & Orcutt et al. (2001) \\
\hline N. Atlantic (May-June 1994) & & 47.1 & Carpenter et al. (2004); Capone et al. (2005) \\
\hline N. Atlantic (April 1996) & & 37.7 & Carpenter et al. (2004); Capone et al. (2005) \\
\hline N. Atlantic (October 1996) & & 24.6 & Carpenter et al. (2004); Capone et al. (2005) \\
\hline Indian Ocean (Tanzania) & & 20 & Lugomela et al. $(2002)^{1}$ \\
\hline Trichodesmium IMS101 (batch) & $4.6-132.5$ & 28 & Mulholland and Capone $(2001)^{2}$ \\
\hline Trichodesmium IMS101 (batch) & $6.5-15.2$ & 9.6 & Mulholland and Capone $(2001)^{3}$ \\
\hline Trichodesmium IMS101 (continuous) & $13.4-20.0$ & & Mulholland and Bernhardt $(2005)^{4}$ \\
\hline $\begin{array}{l}\text { Trichodesmium IMS101 } \\
\text { (semi-continuous) - morning }\end{array}$ & $3.2-10.0$ & 5.4 & Hutchins et al. (2007) \\
\hline $\begin{array}{l}\text { Trichodesmium IMS } 101 \\
\text { (semi-continuous) - afternoon }\end{array}$ & & & Hutchins et al. (2007) \\
\hline Trichodesmium GBRTRLI101 & $2.0-12.4$ & 6.5 & Hutchins et al. (2007) \\
\hline \multicolumn{4}{|l|}{ Other marine cyanobacteria: } \\
\hline Hemiaulus/Richelia association & & 12.5 & Carpenter et al. $(1999)^{5}$ \\
\hline Mixed cyanobacteria - Nodularia spumi- & & $17.6(0-7 \mathrm{~m})$ & Gallon et al. (2002) \\
\hline \multirow[t]{2}{*}{ gena/Anabaena/Aphanizomenon } & & $5.1(7-14 \mathrm{~m})$ & \\
\hline & & $1.5(14-21 \mathrm{~m})$ & \\
\hline
\end{tabular}

${ }^{1}$ Using study averages and recalculating with a conversion factor of $3: 1$.

${ }^{2}$ Mid-day estimate during exponential growth.

${ }^{3}$ Cumulative estimate over a growth or diel cycle. Ratio increased during stationary phase growth.

${ }^{4}$ Lower at faster growth rates.

${ }^{5}$ Calculated using average $\mathrm{N}_{2}$ fixation rate of $0.2 \mathrm{mg} \mathrm{N} \mathrm{m}^{-3} \mathrm{~h}^{-1}$ and average $\mathrm{C}$ fixation rate at bloom stations of $2.14 \mathrm{mg} \mathrm{C} \mathrm{m}^{-3} \mathrm{~h}^{-1}$

(Mahaffey et al., 2005; Mulholland et al., 2006), any fraction of new production from diazotrophy that is exported (e.g., Eppley and Peterson, 1979) to underlying waters will contribute to sequestering atmospheric carbon and so it is important that we gain a better understanding of the coupled $\mathrm{N}$ and $\mathrm{C}$ cycles for these organisms.

\section{$4 \mathrm{~N}$ release}

Trichodesmium spp. can fix $\mathrm{N}_{2}$ at high rates, thereby introducing new nitrogen into nutrient impoverished areas of the tropical and subtropical ocean. Because Trichodesmium also release fixed $\mathrm{N}$ as bioavailable dissolved organic $\mathrm{N}$ (DON) (Glibert and Bronk, 1994; Capone et al., 1994), and am- monium (Mulholland and Capone, 2001; Mulholland et al., 2004a), they may route recently fixed $\mathrm{N}$ through a recycling loop. Elevated $\mathrm{NH}_{4}^{+}$and/or DON concentrations have been observed in and around Trichodesmium blooms in the Arabian Sea (Devassy et al., 1978, 1979), Pacific Ocean (Karl et al., 1992, 1997), the Gulf of Mexico (Lenes et al., 2001), along the coast of Australia (Glibert and O'Neil, 1999) and in aging Trichodesmium cultures (Mulholland and Capone, 2001). However, accumulation of dissolved organic matter $(\mathrm{C}$ or $\mathrm{N})$ is not always observed or predicted, even in areas such as the Sargasso Sea, near the Bermuda Atlantic Time-series Study site (BATS) (Hansell and Carlson, 2001; Hood et al., 2001; Knapp et al., 2005), where $\mathrm{N}_{2}$ fixation is suspected to be high based on geochemical arguments 
(Michaels et al., 1996; Gruber and Sarmiento, 1997). Nutrient concentrations within and around blooms may not always be high if the released $\mathrm{N}$ is rapidly taken up by organisms growing on and around colonies (e.g., see Sellner, 1992, 1997), or by organisms co-occurring in the water column, as has been observed in the Gulf of Mexico (Mulholland et al., 2004b, 2006). In the Baltic Sea, blooms of diazotrophic cyanobacteria (Nodularia and Aphanizomenon) were shown to contribute $\mathrm{N}$ to picoplankton production (Ohlendieck et al., 2000).

In addition to direct release of labile $\mathrm{N}$, viral cell lysis (Ohki, 1999; Hewson et al., 2004), grazing (O'Neil et al., 1996), and cell death (Berman-Frank et al., 2004) may contribute dissolved or particulate $\mathrm{N}$ to the available $\mathrm{N}$ pool. Ohlendieck et al. (2000) demonstrated that direct release of $\mathrm{N}$ was important during the early stages of cyanobacterial blooms while release due to lysing and decay was more important during later blooms stages. Trichodesmium biomass may be degraded via bacterial activity and extracellular enzymes thereby rendering large organic compounds into smaller utilizable compounds (Sieburth and Conover, 1965; Paerl et al., 1989; Nausch, 1996).

$\mathrm{N}$ release from Trichodesmium was first suggested by Devassy et al. (1978) who observed substantial enrichment of phosphate, nitrate and ammonium within, during, and after Trichodesmium blooms and relative to non-bloom sites or at times prior to blooms. Based on changes in nutrient concentrations within incubations, Devassy et al. (1978) estimated $1.5 \mu \mathrm{mol} \mathrm{N}$ (as inorganic $\mathrm{N}$ ) and $6.8 \mu \mathrm{mol}$ inorganic $\mathrm{P}$ were released per $\mathrm{g}$ of Trichodesmium. These authors also suggested that these release rates would have been much higher if DOP, urea and amino acids had been measured.

In general, $\mathrm{N}$ release has been difficult to estimate using isotopic tracer or other methods for a number of reasons: 1) release products may be diverse and so it is often difficult to isolate and measure all relevant dissolved pools, 2) release products are rapidly taken up by organisms in oligotrophic environments, and 3) intracellular pools of intermediate metabolites can accumulate before their release for variable amounts of time thus making it impossible to measure isotopically-labeled products in short incubations. To get around these problems, it has been suggested that the difference between net and gross $\mathrm{N}_{2}$ fixation measured using ${ }^{15} \mathrm{~N}_{2}$ uptake and acetylene reduction techniques, respectively, might be a good metric of $\mathrm{N}$ release (Gallon et al., 2002; Mulholland et al., 2004a, 2006).

High $\mathrm{N}$ release rates would seem to argue for high cellular $\mathrm{N}$ turnover, however, if $\mathrm{N}$ is released prior to its assimilation into biomass, this would contribute to gross $\mathrm{N}_{2}$ fixation (e.g., reduction of $\mathrm{N}_{2}$ to $\mathrm{NH}_{4}^{+}$) but not net uptake into biomass. In numerous paired comparisons between acetylene reduction and ${ }^{15} \mathrm{~N}_{2}$ uptake, ratios of acetylene $\left(\mathrm{C}_{2} \mathrm{H}_{2}\right)$ reduced to $\mathrm{N}_{2}$ taken up have varied by at least an order of magnitude (Table 2). Because $\mathrm{C}_{2} \mathrm{H}_{2}$ reduction measures just the reduction step, it is a measure of gross $\mathrm{N}_{2}$ fixation while movement of ${ }^{15} \mathrm{~N}_{2}$ from the dissolved to the particulate pool measures net $\mathrm{N}$ assimilation (see Gallon et al., 2002; Mulholland et al., 2004a, 2006; Mulholland and Bernhardt, 2005). Release of recently fixed $\mathrm{N}_{2}$ and the difficulty in chemically recovering all possible dissolved pools into which products of $\mathrm{N}_{2}$ fixation might be released, may make intercalibration between the two methods impossible. However, the difference between $\mathrm{N}_{2}$ reduction (gross $\mathrm{N}_{2}$ fixation) and net $\mathrm{N}_{2}$ assimilation may prove to be an excellent index of the release of recently fixed $\mathrm{N}_{2}$ (Gallon et al., 2002; Mulholland et al., 2004a, 2006; Mulholland and Bernhardt, 2005). If this is the case, and the theoretical ratio, three, is assumed to be correct (although this itself is a subject of debate; see Mulholland et al., 2006, for a discussion of this assumption) in estimating $\mathrm{N}_{2}$ fixation from $\mathrm{C}_{2} \mathrm{H}_{2}$ reduction, paired comparisons in which $\mathrm{C}_{2} \mathrm{H}_{2}: \mathrm{N}_{2}$ reduction ratios of approximately 3:1 are observed, would indicate no $\mathrm{N}$ release while $\mathrm{C}_{2} \mathrm{H}_{2}: \mathrm{N}_{2}$ reduction ratios of six would translate into a release rate of about $50 \%$, and so on. Examining paired comparisons of $\mathrm{C}_{2} \mathrm{H}_{2}$ reduction and ${ }^{15} \mathrm{~N}_{2}$ uptake from recent studies and the literature (Table 1), rates of release of recently fixed $\mathrm{N}$ can be compared across systems and with respect to temperature. Results demonstrate that release rates are highly variable on a variety of temporal and spatial scales. Release rates appeared to be high in populations collected from a South $\mathrm{Pa}$ cific lagoon, varied seasonally in the North Atlantic along a latitudinal gradient, and on a daily and interannual basis in the Gulf of Mexico (Table 2). In cultures, release rates varied with the growth rate (Mulholland and Bernhardt, 2005) and with the time of day (Table 2). Based on various studies where ${ }^{15} \mathrm{~N}_{2}$ and acetylene reduction were compared directly, it appears that $\mathrm{N}$ release from Trichodesmium is common but varies with physiological state (Mulholland et al., 2004a; Mulholland and Bernhardt, 2005) and among environments (Table 2 and references therein). One paired comparison is available for a diatom/Richelia association (Table 2; Carpenter et al., 1999) and suggests that there was $\mathrm{N}$ release from $\mathrm{N}_{2}$ fixation for this association as well. No published paired comparisons of $\mathrm{C}_{2} \mathrm{H}_{2}: \mathrm{N}_{2}$ reduction for unicells are available and so release by these organisms cannot be assessed at this time.

While there have been observations that Trichodesmium release recently fixed $\mathrm{N}_{2}$ as DON in natural populations (Capone et al., 1994; Glibert and Bronk, 1994) and as $\mathrm{NH}_{4}^{+}$ in cultures of Trichodesmium IMS101 (Mulholland et al., 2004a; Mulholland and Bernhardt, 2005) it is unclear why cells do this or whether they do so all the time. Previous speculation suggested that this is a mechanism for the extracellular transfer of fixed $\mathrm{N}$ between cells that fix $\mathrm{N}_{2}$ and those that do not have that capability (Mulholland and Capone, 1999, 2000). Another possible fate for released $\mathrm{N}$ is co-occurring organisms (O'Neil et al., 1996; Mulholland et al., 2004b, 2006). Release rates averaged about $52 \%$ of the recently fixed $\mathrm{N}_{2}$ or $0.29 \mathrm{nmol} \mathrm{col}^{-1} \mathrm{~h}^{-1}$ in a recent study in the Gulf of Mexico (Mulholland et al., 2006), and much of this may 
have fueled production of co-occurring phytoplankton (Mulholland et al., 2004b). In diatoms, it has been suggested that nitrate uptake in excess of their nutritional requirements may act as a sink for electrons when there are transient imbalances between light energy harvesting and photosynthetic carbon assimilation (Lomas and Glibert, 1999; Lomas et al., 2000). These authors speculate that imbalances between these processes, and associated release of dissolved $\mathrm{N}$, occur when cells shift from high to low temperature or low to high irradiance. Trichodesmium tend to occur in tropical and subtropical oligotrophic gyres where the water column and surface water temperatures are relatively stable. However, they are also known to form surface accumulations or "slicks" during which exposure irradiances are quite high and release of dissolved substances also high (e.g., Sieburth and Conover, 1965).

$\mathrm{N}$ release from cellular material can also be mediated through cell lysis. Viruses and a lytic cycle have been observed in natural populations and cultures of Trichodesmium (Ohki, 1999). Hewson et al. (2004) estimated lysis rates of 0.3 to $6.5 \%$ trichomes $\mathrm{d}^{-1}$, representing a release of 3 to $65 \%$ of the production for Trichodesmium growing at $0.1 \mathrm{~d}^{-1}$. While these authors report this as 3 to $65 \%$ of recently fixed $\mathrm{N} \mathrm{d}^{-1}$, this also applies to $\mathrm{C}$ (see below). At an average rate of 43 pmol $\mathrm{N}$ fixed trichome $\mathrm{e}^{-1} \mathrm{~d}^{-1}$, this represents a release rate of 1.3 to $28 \mathrm{pmol}$ trichome $\mathrm{e}^{-1} \mathrm{~d}^{-1}$ or (using an average colony size of 100 trichomes $\mathrm{col}^{-1}$ ) 13 to $280 \mathrm{pmol}$ $\mathrm{col}^{-1} \mathrm{~d}^{-1}$. These estimates agree well with the mortality rates calculated for Trichodesmium at BATS and in the equatorial Atlantic (2.1 to $2.5 \% \mathrm{~d}^{-1}$; Hood et al., 2001, 2004).

\section{C release}

Dissolved organic N contains $\mathrm{C}$ and so it is therefore logical to assume that Trichodesmium also release substantial amounts of photosynthetic products as dissolved organic carbon (DOC). In fact, Shimura at al. (1978) first quantified the extracellular release of photosynthate in ${ }^{14} \mathrm{C}$ incubations and calculated that about $8 \%$ of the total photosynthetic products were released during incubation experiments (range 0-18\%). Similarly, Gallon et al. (1996) estimated that DOC excretion by Trichodesmium in the western North Atlantic and eastern Caribbean Sea represented 7\% of the primary productivity, and, as for $\mathrm{N}$, the amount of $\mathrm{C}$ released changed depending on light conditions and the physiological status of cells. More recently, Renaud et al. (2005) estimated a much lower value (1\%) for DOC release by Trichodesmium. However, they suggested that tight coupling between organisms in the Trichodesmium consortium might cause underestimates of actual release rates. Thus, the same methodological limitations that make it difficult to estimate $\mathrm{N}$ release from tracer studies make it difficult to make estimates of $\mathrm{C}$ release; just as ${ }^{15} \mathrm{~N}_{2}$ uptake can underestimate gross $\mathrm{N}_{2}$ fixation, ${ }^{14} \mathrm{C}$ (or
${ }^{13} \mathrm{C}$ ) incorporation can underestimate the gross rate of photosynthetic carbon fixation (Gallon et al., 2002).

Cyanobacteria release compounds such as glycolate (Renström-Kellner et al., 1989) and amino acids (Capone et al., 1994). Amino acid release as glutamine and glutamate (molar C:N ratios of 5:2 and 5:1, respectively) represented only $3 \%$ of the C fixed by Trichodesmium (Capone et al., 1994). However, Trichodesmium have a carbohydrate mucoid matrix, which is colonized by other organisms (Stal, 1995; Sellner, 1997; Sheridan et al., 2002) and so there is a constant production of glucose- and mannose-rich mucilage that could account for more DOC release (e.g., Sellner, 1997). Cyanobacteria in general can exude as much as $80 \%$ of the $\mathrm{CO}_{2}$ they fix as extracellular polymeric substances (mainly polysaccharides) (Sellner, 1997).

Production of colored dissolved organic matter (CDOM) by Trichodesmium has recently been observed (Steinberg et al., 2004). Production of DOC ranged from 0.04 to $0.32 \mu \mathrm{g}$ $\mathrm{C} \mathrm{col}^{-1} \mathrm{~h}^{-1}$. Assuming an average of $11.3 \mu \mathrm{g} \mathrm{C} \mathrm{col}^{-1}$ (McCarthy and Carpenter, 1979), this represents between 0.4 and $2.8 \% \mathrm{~h}^{-1}$ or up to $67 \% \mathrm{~d}^{-1}$, although it is unclear whether this production is confined to the dark or light periods. The CDOM had absorption spectra similar to microsporinlike amino acids, compounds that Trichodesmium are know to have and serve in photoprotection (Subramaniam et al., 1999).

Although globally we are interested in the fate of new production from diazotrophy as a means to export $\mathrm{C}$, little has been done to quantify or characterize DOC release and its fate from Trichodesmium or other marine $\mathrm{N}_{2}$ fixers. Robust isotopic and molecular tracers of diazotroph-derived DOC have yet to be identified. If we are to extrapolate export from production of $\mathrm{N}_{2}$ fixers, it will be important to determine the primary pathways of $\mathrm{C}$ flow through these organisms.

\section{Trophic interactions}

It is impossible to discuss the fate of new production by diazotrophs without discussing trophic interactions. Colonies of Trichodesmium provide stable "homes" for a numerous and diverse association of organisms (Siddiqui et al., 1992; Sellner, 1997; O'Neil, 1999; Sheridan et al., 2002). This creates a complex microenvironment with multifarious pathways for internal nutrient cycling. Sheridan et al. (2002) estimated that $85 \%$ of Trichodesmium colonies were inhabited by other organisms. Colonizing organisms include bacteria, other cyanobacteria, fungi, pennate and centric diatoms, heterotrophic and autotrophic dinoflagellates, chrysophytes, ciliates, amoebae, hydroids, different life stages of harpacticoid copepods and juvenile decapods. Bacteria and dinoflagellates were the most common associates (Sheridan et al., 2002). Despite the fact that colonies are rich microenvironments, there is a variety of evidence suggesting that Trichodesmium themselves go largely ungrazed (see 


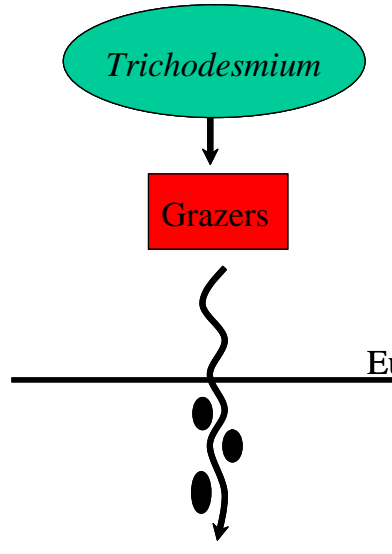

Sinking

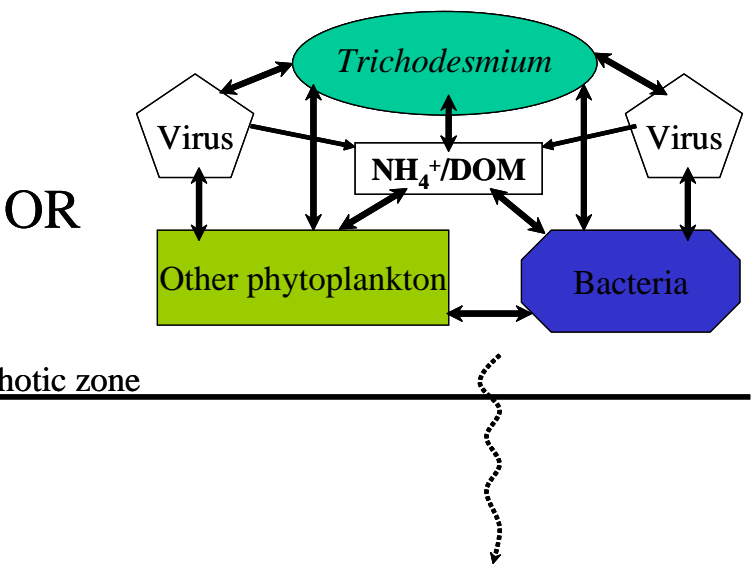

Sinking

Fig. 1. Pathways of trophic transfer promoting (A) sinking flux and (B) carbon flow through a microbial loop with no net carbon export.

below) and so viral cell lysis and decomposition are the likely fates for many of these populations (nutrient accumulation), and that the importance of higher trophic levels in processing Trichodesmium biomass is minimal as compared to recycled primary production and bacterial productivity.

Consistent with this idea is the observation that a variety of phytoplankton, bacteria, and higher trophic levels cooccur or occur in the water column subsequent to blooms of Trichodesmium spp. (Devassy, 1978, 1979; Revelante et al., 1982; Furnas and Mitchell, 1996; Walsh and Steidinger, 2001; Mulholland et al., 2006). It is thought that these communities are relieved from $\mathrm{N}$ limitation as a result of $\mathrm{N}$ release from Trichodesmium.

Trichodesmium occur as variously sized and shaped aggregates or colonies but also as free filaments or trichomes. Large colonies may contain hundreds of trichomes. However, the average colony size and colony abundance can vary from day to day (Devassy et al., 1978). Colonies take the form of bundles with trichomes arranged in parallel (tufts) or radially (puffs). Little is known about the causes of bundle formation, but the distributions of free filaments and bundles vary regionally and apparently with the degree of turbulence (Bryceson and Fay, 1981; Mahaffey et al., 2005). The purpose of bundle formation is also unclear, but there has been speculation that it may be a behavioral strategy for minimizing the exposure of nitrogenase (an oxygen sensitive protein) to oxygen (e.g., Paerl et al., 1989; Gallon, 1992). Regardless of the reasons colonies form, the trophodynamics of Trichodesmium vary depending on morphology, the amount of stable surface area, and interfilamental space available for colonization.

There are few direct measurements of the trophic transfer of recently fixed $\mathrm{N}$ or $\mathrm{C}$ through Trichodesmium. Bryceson and Fay (1981) first demonstrated that the trophic transfer of recently fixed $\mathrm{N}_{2}$ might be important in communities dominated by Trichodesmium and they subsequently demonstrated isotopic enrichment in non-Trichodesmium size fractions after incubation of Trichodesmium and natural marine communities with ${ }^{15} \mathrm{~N}_{2}$. They did not have control incubations to account for $\mathrm{N}_{2}$ fixation by smaller diazotrophic cyanobacteria and bacterioplankton but, nevertheless, they report enrichment in the 2 to $30 \mu \mathrm{m}$ and 0.2 to $2.0 \mu \mathrm{m}$ size fractions (Bryceson and Fay, 1981). Subsequently, the only other direct estimates of the trophic transfer of recently fixed $\mathrm{N}_{2}$ demonstrated that up to $11 \%$ of recently fixed $\mathrm{N}_{2}$ was transferred to non- $\mathrm{N}_{2}$ fixing cells in whole water samples even in short (2 h) incubations (Mulholland et al., 2004b). This suggests that Trichodesmium may support further productivity in the upper water column and the growth of cooccurring organisms, including heterotrophs, rather than a substantial direct particle sinking flux (Fig. 1).

Despite the idea that dissolved nutrients may be the primary route of trophic transfer of recently fixed $\mathrm{N}_{2}$, isotopically "light" zooplankton have been collected from the tropical Atlantic (Montoya et al., 2002) and isotopically light sediment trap material was collected under a station experiencing a Trichodesmium bloom in the Indian Ocean (Capone et al., 1998). In addition, low $\delta^{15} \mathrm{~N}$ values have been reported in sediment trap material at both the Atlantic and Pacific time series sites (Karl et al., 1997, 2002; Knapp et al., 2005), indicating that recently fixed $\mathrm{N}_{2}$, which has an isotopic signature similar to atmospheric $\mathrm{N}$, is being transferred to higher trophic levels and leaving the euphotic zone.

In contrast, Brandes et al. (1998) suggested that material derived from $\mathrm{N}_{2}$ fixation could also be remineralized in the upper water column and hypothesized that the input of isotopically light $\mathrm{N}$ from $\mathrm{N}_{2}$ fixation was responsible for a lightening of the isotopic nitrate signal in surface waters above the oxygen minimum zone in the Arabian Sea. Based on excess $\mathrm{N}_{2}$ gas concentrations, Devol (2007) and Devol et 
al. (2006) have gone on to speculate that the particle rain from diazotrophic production fuels denitrification in the oxygen minimum zone there. These observations suggest that diazotrophic production can be remineralized in surface waters fueling microbial production and complicating interpretation of geochemical tracers such as stable isotope signatures and $\mathrm{N}^{*}$.

\subsection{Bacteria}

Bacterial associates with Trichodesmium colonies have been widely observed (Paerl et al., 1989; Nausch, 1996; Sheridan et al., 2002; Renaud et al., 2005; Mulholland et al., unpublished data). Trichodesmium colonies are inhabited by both rod-shaped and filamentous bacteria, as are many other filamentous cyanobacteria (Paerl et al., 1989). Bacterial associates also included heterotrophic $\mathrm{N}_{2}$ fixers, were located around and within aggregates where they took up carbohydrates and amino acids.

Varying degrees of enrichment of bacteria have been found on and around colonies. Nausch (1996) reported that bacteria were 2 to 5 times higher on colonies of Trichodesmium than in the surrounding water, however, during her study, Trichodesmium were not abundant, the water column was turbulent, and colonies were small. At BATS, Sheridan et al. (2002) report that bacteria were enriched on average 401 and 1709 times on Trichodesmium puffs and tufts, respectively. Carpenter and Price (1977) found that up to 8.3\% of Trichodesmium were populated by bacteria in the Sargasso Sea. So, it appears that there is high variability in the degree of bacterial colonization of Trichodesmium aggregates.

In terms of their productivity, Nausch (1996) found thymidine incorporation to be enhanced in association with colonies of Trichodesmium relative to that of the water column and comparable to the enrichment found in marine snow. However, because colony-associated bacterial abundance was so much higher, when normalized per unit bacteria, thymidine incorporation associated with colonies appeared to be lower than that measured in the surrounding water. In the Gulf of Mexico, leucine incorporation increased by up to $72 \%$ in association with Trichodesmium colonies relative to the surrounding water column (Mulholland et al., unpublished data). Similarly, Tseng et al. (2005) found that bacterial productivity and abundance were higher but productivity per unit bacterial biomass was lower, in association with Trichodesmium populations. In addition, they found that populations became more autotrophic during times of the year when Trichodesmium was abundant (lower bacterial productivity: primary productivity ratio). The authors attribute this to $\mathrm{N}$ release and alleviation of competition between bacteria and phytoplankton for scarce $\mathrm{NH}_{4}^{+}$. However, they also note that Trichodesmium occurred as free filaments in the Kuroshio and therefore lacked harpacticoid grazer populations and associated organisms observed in other communities (Tseng et al., 2005).
High rates of amino acid oxidase activity (Mulholland et al., 1998; Glibert and O'Neil 1999), peptide hydrolysis (Mulholland et al. unpublished data), and hydrolytic enzyme activity have also been found in association with Trichodesmium colonies, suggesting bacteria and other organisms (e.g., phytoplankton and grazers) associated with colonies actively cycle nutrients. Rates of enzyme activity in and around colonies in these studies were higher than those observed in the surrounding water column reflecting either more active or more abundant microbial communities. Nausch (1996) calculated $\mathrm{C}$ and $\mathrm{N}$ release rates between 30.5 and $1086 \mathrm{ng} \mathrm{Col}^{-1} \mathrm{~h}^{-1}$ and 4.6 to $209 \mathrm{ng} \mathrm{N} \mathrm{col}^{-1} \mathrm{~h}^{-1}$, respectively, based on hydrolytic enzyme activities associated with Trichodesmium colonies.

\subsection{Phytoplankton}

In some coastal systems, blooms of dinoflagellates and diatoms have been observed during and subsequent to Trichodesmium blooms (Devassy et al., 1978; Revelante et al., 1982; Furnas and Mitchell, 1996). For example, Devassy et al. (1979) found that as blooms of Trichodesmium decayed, Chaetoceras populations increased, followed by a succession of cladocerans, dinoflagellates, green algae, copepods, and finally, carnivores. On the West Florida shelf, dense Karenia brevis blooms occur during and subsequent to Trichodesmium blooms and it has been hypothesized that they provide a source of new $\mathrm{N}$ to fuel destructive red tides (Walsh and Steidinger, 2001; Mulholland et al., 2006). Based on direct estimates of $\mathrm{N}_{2}$ fixation, $\mathrm{N}$ release, and in situ water column $\mathrm{N}$ uptake rates, Trichodesmium produced ample dissolved $\mathrm{N}$ to fuel $K$. brevis growth in the Gulf of Mexico (Mulholland et al., 2006).

Experiments suggest that Tetraselmis grew well on decaying Trichodesmium (Devassy et al., 1978). Similarly, Karenia brevis cultures grew well on culture medium enriched in Trichodesmium exudates as the sole source of nitrogen (Mulholland et al., unpublished data). Although direct evidence of trophic transfer from Trichodesmium to phytoplankton in nature is lacking, Bryceson and Fay (1981) and Mulholland et al. (2004b), demonstrated that ${ }^{15} \mathrm{~N}$ derived from ${ }^{15} \mathrm{~N}_{2}$ additions moved into the co-occurring plankton, which presumably included a variety of phytoplankton. Further, the low $\delta^{15} \mathrm{~N}$ observed in sediment trap material suggests that at least some $\mathrm{N}$ derived from diazotrophy is leaving the euphotic zone (Karl et al., 1997, 2002; Capone et al., 1998; Montoya et al., 2002; Knapp et al., 2005).

\subsection{Zooplankton and higher trophic levels}

The fate of recently fixed $\mathrm{N}_{2}$ and transfer of Trichodesmium biomass to higher trophic levels is poorly understood. Although a variety of herbivores are thought to graze on Trichodesmium (e.g., Sellner, 1997), Trichodesmium spp. are not grazed by many of the dominant zooplankton in marine 


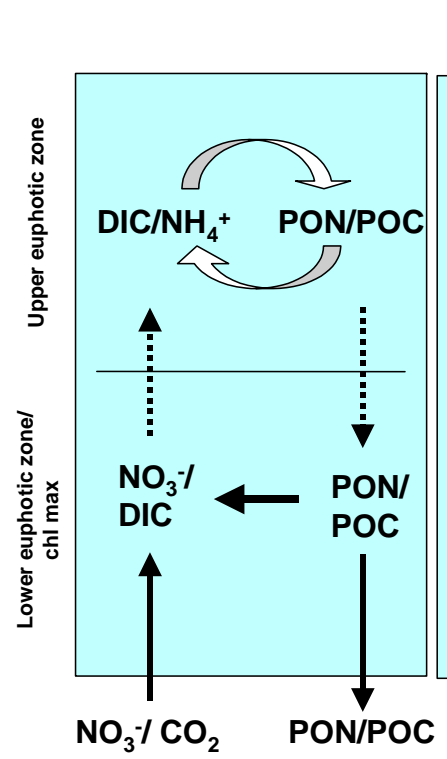

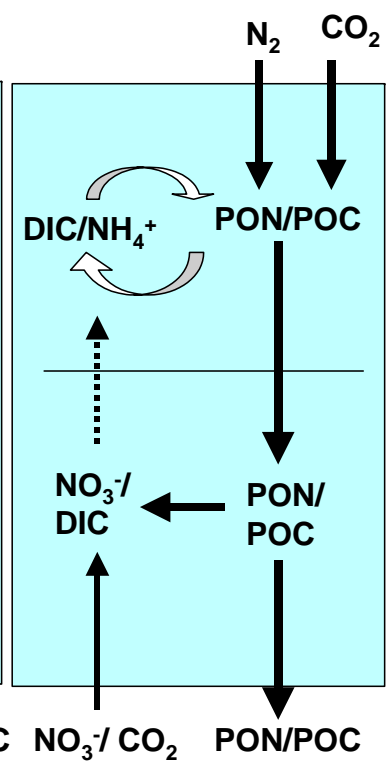

B. $\mathrm{N}_{2}$ fixation \& export

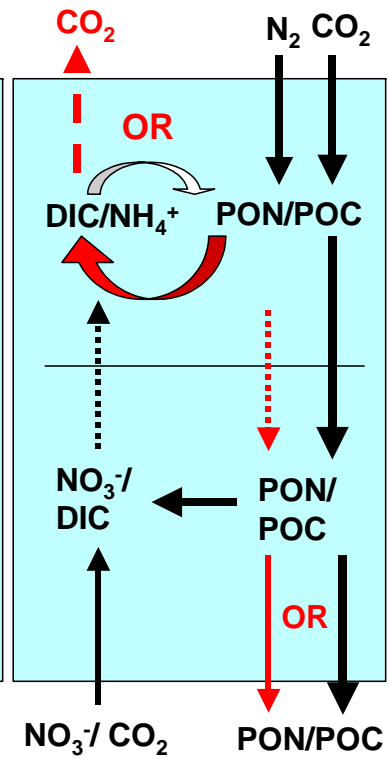

C. $\mathrm{N}_{2}$ fixation \& remineralization

Fig. 2. Nitrogen and carbon cycling in the oligotrophic ocean with and without $\mathrm{N}_{2}$ fixation. Panel (A) represents an ocean without $\mathrm{N}_{2}$ fixation, where new nitrate upwelled from below the euphotic zone balances export of material out of the euphotic zone. Panel (B) represents an oligotrophic gyre with $\mathrm{N}_{2}$ fixation and associated export of new diazotrophic production. Panel (C) represents an alternative fate for diazotrophic production wherein new production is respired in the euphotic zone or surface ocean, and results in no net drawdown or export of carbon or nitrogen from the euphotic zone (red). Redrawn and expanded from Hood et al. (2000).

systems and are toxic to many copepods (Hawser and Codd, 1992; O’Neil, 1999). Some specialized harpacticoid copepods do graze on and inhabit Trichodesmium colonies but these do not produce fecal pellets that would rapidly remove grazed material from the euphotic zone (O'Neil and Roman, 1994; O’Neil et al., 1996).

O'Neil et al. (1996) estimated that the harpacticoid copepod, Macrosetella, could consume 33-45\% of total colony $\mathrm{N}$, or $100 \%$ of the new $\mathrm{N}_{2}$ fixed each day. The copepod then excretes $48 \%$ of its body $\mathrm{N}$ per day, mainly as $\mathrm{NH}_{4}^{+}$, thereby recycling much of the $\mathrm{N}$ in the water column (O'Neil et al., 1996). Further, Roman (1978) found that Macrosetella could ingest from 90 to $126 \%$ of its body carbon per day when feeding on Trichodesmium. Based on stoichiometric arguments, O'Neil (1999) calculated 30\% of the recently fixed $\mathrm{C}$ from Trichodesmium spp. flowed into grazers and because Macrosetella appears to have a higher C:N ratio than the Trichodesmium spp. themselves, they are likely to excrete excess $\mathrm{N}$. Therefore, the major flux of recently fixed $\mathrm{N}$ and $\mathrm{C}$ through zooplankton may also be through extracellular release and dissolved nutrient pools. In addition to excretory release, zooplankton grazers can mediate the transfer of $\mathrm{N}$ through additional release from sloppy feeding (O'Neil and Roman, 1996).

Not much is known about higher trophic levels, although isotopic evidence suggests that there are other grazers of Tri- chodesmium (e.g., Montoya et al., 2002). In general, it has been observed that there is a low quality of fish associated with blooms, although Trichodesmium do not appear to be directly toxic to fish (Devassy et al., 1978). Fish and some other higher trophic levels have been observed to graze on Trichodesmium (see Carpenter and Capone, 2007).

\section{Implications}

While we appear to be making strides in our ability to derive global estimates for marine $\mathrm{N}_{2}$ fixation, we have a long way to go before we understand the role of diazotrophy in the context of $\mathrm{N}$ and $\mathrm{C}$ dynamics in the ocean. Because many direct estimates of global $\mathrm{N}_{2}$ fixation are based on highly spatially, temporally, and physiologically limited and variable data, and because many geochemical estimates rely on stoichiometric relationships of nutrient standing stocks without considering the imbalances between rate estimates of $\mathrm{C}$ and $\mathrm{N}_{2}$ fixation, we should proceed cautiously when inferring one from the other (see examples in Sect. 3 above). Based on the observed $\mathrm{C}$ drawdown from the atmosphere, we may be trying to find "too much" $\mathrm{N}_{2}$ fixation if we use Redfield stoichiometry versus the observed relative rates of $\mathrm{C}$ and $\mathrm{N}_{2}$ fixation. Further, because we know so little about the physiology of marine diazotrophs, it is difficult to model the contribution of new production from diazotrophy in the 
present, past, or future ocean where conditions vary in space and time.

It is also difficult to determine the effect of $\mathrm{N}_{2}$ fixation on system trophic status. In some systems Trichodesmium appears to fuel primary productivity and make the system more autotrophic (e.g., Tseng et al., 2005). In other systems dominated by Trichodesmium, heterotrophic processes appear to dominate (Fig. 2; also see Sect. 6.3 above). For example, it was observed that along the Kenyan coast, primary productivity, even during Trichodesmium blooms, could barely sustain the observed bacterial productivity (Kromkamp et al., 1997).

The preponderance of filaments versus colonial morphology can also seriously bias our understanding of trophodynamics associated with Trichodesmium and the net outcome of elemental cycling (e.g., recycling and respiratory losses versus export). Not only does colony size affect colony-specific estimates of $\mathrm{N}$ and $\mathrm{C}$ fixation, but the degree of aggregation and size of colonies also affects the degree to which Trichodesmium is colonized by other organisms and thereby recycled via bacteria, grazers, and other enzymatically-mediated processess. Free filaments often dominate populations in the Pacific (Saino and Hattori, 1978, 1980; Letelier and Karl, 1996; Tseng et al., 2005) and the Atlantic, at least seasonally (Orcutt et al., 2001) although in many systems, colonies appear to be more common (Capone et al., 1997; Carpenter et al., 2004). Better common metrics need to be employed to express rate measurements not only because Trichodesmium morphologies vary, but also because we now know there are a variety of non-Trichodesmium diazotrophs.

Finally, different diazotrophic groups may have different fates and we know even less about non-Trichodesmium marine $\mathrm{N}_{2}$ fixers. Diatom/Richelia assemblages may be prone to gravitational settling while unicellular cyanobacteria may be more readily grazed. There are a variety of conflicting reports based on isotopic and geochemical tracers suggesting that diazotrophic growth fuels export production versus remineralization. The absence of robust direct estimates of both, hinder our ability to speculate regarding the fate of new $\mathrm{N}$ from diazotrophic growth.

Acknowledgements. Funding for this project was provided by the National Science Foundation, grants OCE-0095923 and OCE-0136367 to MRM. The author also wishes to thank M. Voss, W. Naqvi, and an anonymous reviewer for their comments on earlier versions of this manuscript, the organizers of the Significant Processes, Observations and Transformations in Oceanic Nitrogen (SPOT-ON) workshop (M. Voss, S. W. A. Naqvi, and J. P. Montoya) for the opportunity to contribute to the workshop and this special volume, and C. Dupuoy and A. Leboutellier for their invitation and support to participate in field work in New Caledonia.

Edited by: S. W. A. Naqvi

\section{References}

Badger, M. R. and Price, G. D.: $\mathrm{CO}_{2}$ concentrating mechanisms in cyanobacteria: molecular components, their diversity and evolution, J. Exp. Botany, 54, 609-622, 2003.

Berman-Frank, I., Bidle, K. D., Haramaty, L., and Falkowski, P. G.: The demise of the marine cyanobacterium, Trichodemsium spp., via an autocatalyzed cell death pathway, Limnol. Oceanogr., 49, 997-1005, 2004.

Brandes, J. A., Devol, A. H., Yoshinari, T., Jayakumar, D. A., and Naqvi, S. W. A.: Isotopic composition of nitrate in the central Arabian Sea and eastern tropical North Pacific: a tracer for mixing and nitrogen cycles, Limnol. Oceanogr., 43, 1680-1689, 1998.

Breitbarth, E., Oschlies, A., and LaRoche, J.: Physiological constraints on the global distribution of Trichodesmium - effect of temperature on diazotrophy, Biogeosciences Discuss., 6, 779801, 2006,

http://www.biogeosciences-discuss.net/6/779/2006/.

Bryceson, I. and Fay, P.: Nitrogen fixation in Oscillatoria (Trichodesmium) erythraea in relation to bundle formation and trichome differentiation, Mar. Biol., 61, 159-166, 1981.

Capone, D. G.: Determination of nitrogenase activity in aquatic samples using the acetylene reduction procedure, pp. 621-631, in: Handbook of Methods in Aquatic Microbial Ecology, edited by: Kemp, P. F., Sherr, B. F., Sherr, E. B., and Cole, J. J., Lewis Publishers, 1993.

Capone, D. G.: Marine nitrogen fixation: what's the fuss?, Current Opinion in Microbiology, 4, 341-348, 2001.

Capone, D. G., Burns, J. A., Montoya, J. P., Subramaniam, A., Mahaffey, C., Gunderson, T., Michaels, A. F., and Carpenter, E. J.: Nitrogen fixation by Trichodesmium spp.: an important source of new nitrogen to the tropical and subtropical North Atlantic Ocean, Global Biogeochem. Cycles, 19, GB2024, doi:10.1029/2004GB002331, 2005.

Capone, D. G. and Carpenter, E. J.: Nitrogen fixation by marine cyanobacteria: Historical and global perspectives, Bull. Inst. Oceanogr. Monaco, 19, 235-256, 1999.

Capone, D. G., Ferrier, M. D., and Carpenter, E. J.: Amino acid cycling in colonies of the planktonic marine cyanobacterium, Trichodesmium thiebautii, Appl. Environm. Microbiol., 60, 39893995, 1994.

Capone, D. G., Subramaniam, A., Montoya, J. P., Voss, M., Humborg, C., Johansen, A. M., Siefert, R. L., and Carpenter, E. J.: An extensive bloom of the $\mathrm{N}_{2}$-fixing cyanobacterium Trichodesmium erythraeum in the central Arabian Sea, Mar. Ecol. Prog. Ser., 172, 281-292, 1998.

Capone, D. G., Zehr, J. P., Paerl, H. W., Bergman, B., and Carpenter, E. J.: Trichodesmium, a globally significant marine cyanobacterium, Science, 276, 1221-1229, 1997.

Carpenter, E. J. and Capone, D. G.: Nitrogen fixation in the marine environment, in: Nitrogen in the Marine Environment, edited by: Capone, D. G., Bronk, D. A., Mulholland, M. R., and Carpenter, E. J., in press, 2007.

Carpenter, E. J., Chang, J., Cottrell, M., Schubauer, J., Paerl, H. W., Bebout, B. M., and Capone, D. G.: Re-evaluation of nitrogenase oxygen-protective mechanisms in the planktonic marine cyanobacterium Trichodesmium, Mar. Ecol. Prog. Ser., 65, 151158, 1990.

Carpenter, E. J. and McCarthy, J. J.: Nitrogen fixation and up- 
take of combined nitrogenous nutrients by Oscillatoria (Trichodesmium) thiebautii in the western Sargasso Sea, Limnol. Oceanogr., 20, 389-401, 1975.

Carpenter, E. J., Montoya, J. P., Burns, J., Mulholland, M. R., Subramaniam, A., and Capone, D. G.: Extensive bloom of a $\mathrm{N}_{2}$ fixing symbiotic association in the tropical Atlantic Ocean, Mar. Ecol. Prog. Ser., 185, 273-283, 1999.

Carpenter, E. J. and Price IV, C. C.: Nitrogen fixation, distribution, and production of Oscillatoria (Trichodesmium) spp. in the western Sargasso and Caribbean Seas, Limnol. Oceanogr., 22, 60-72, 1977.

Carpenter, E. J. and Roenneberg, T.: The marine planktonic cyanobacteria Trichodesmium spp.: photosynthetic rate measurements in the SW Atlantic Ocean, Mar. Ecol. Prog. Ser., 118, 267273, 1995 .

Carpenter, E. J., Subramaniam, A., and Capone, D. G.: Biomass and primary productivity of the cyanobacterium Trichodesmium spp. in the tropical N Atlantic Ocean, Deep-Sea Res. I, 51, 173-203, 2004.

Devassy, V. P., Bhattathiri, P. M. A., and Qasim, S. Z.: Trichodesmium phenomenon, Ind. J. Mar. Sci., 7, 168-186, 1978.

Devassy, V. P., Bhattathiri, P. M., and Qasim, S. Z.: Succession of organisms following Trichodesmium phenomenon, Ind. J. Mar. Sci., 8, 89-93, 1979.

Devol, A. H.: Denitrification, in: Nitrogen in the Marine Environment, edited by: Capone, D. G., Bronk, D. A., Mulholland, M. R., and Carpenter, E. J., in press, 2007.

Devol, A. H., Uhlenhopp, A. G., Naqvi, S. W. A., Brandes, J. A., Jayakumar, D. A., Naik, H., Gaurin, S., Codispoti, L. A., and Yoshinari, T.: Denitrification rates and excess nitrogen gas concentrations in the Arabian Sea oxygen deficient zone, Deep-Sea Res. I, 53, 1533-1547, 2006.

Dore, J. E., Brum, J. R., Tupas, L. M., and Karl, D. M.: Seasonal and interannual variability insources of nitrogen supporting export in the oligotrophic subtropical North Pacific Ocean, Limnol. Oceanogr., 47, 1595-1607, 2002.

Dugdale, R. C. and Goering, J. J.: Uptake of new and regenerated forms of nitrogen in primary productivity, Limnol. Oceanogr., 121, 196-206, 1967.

Eppley, R. W. and Peterson, B. J.: Particulate organic matter flux and planktonic new production in the deep ocean, Nature, 282, 677-680, 1979.

Falcón, L. I., Carpenter, E. J., Cipriano, F., Bergman, B., and Capone, D. G.: $\mathrm{N}_{2}$ fixation by unicellular bacterioplankton from the Atlantic and Pacific oceans: phylogeny and in situ rates, Appl. Environ. Microbiol., 70, 765-770, 2004.

Fu, F.-X, Zhang, Y., Leblanc, K., Sañudo-Wilhelmy, S. A., and Hutchins, D. A.: The biological and biogeochemical consequences of phosphate scavenging onto phytoplankton cell surfaces, Limnol. Oceanogr., 50, 1459-1472, 2005.

Furnas, M. J. and Mitchell, A. W.: Pelagic primary production in the Coral and southern Solomon Seas, Mar. Freshwater Res., 47, 395-705, 1996.

Gallon, J. R.: Reconciling the incompatible: $\mathrm{N}_{2}$ fixation and $\mathrm{O}_{2}$, New Phytol., 122, 571-601, 1992.

Gallon, J. R., Evans, A. M., Jones, D. A., Albertano, P., Congestri, R., Bergman, B., Gundersen, K., Orcutt, K. M., von Bröckel, K., Fritsche, P., Meyerhöfer, M., Nachtigall, K., Ohlendieck, U., te Lintel Hekkert, S., Sivonen, K., Repka, S., Stal, L. J., and Staal,
M.: Maximum rates of $\mathrm{N}_{2}$ fixation and primary production are out of phase in a developing cyanobacterial bloom in the Baltic Sea, Limnol. Oceanogr., 47, 1514-1521, 2002.

Gallon, J. R., Jones, D. A., and Page, T. S.: Trichodesmium, the paradoxical diazotroph, Algological Studies, 83, 215-243, 1996.

Galloway, J. R., Dentener, F. J., Capone, D. G., et al.: Nitrogen Cycles: Past, Present and Future, Biogeochemistry, 70, 153-226, 2004.

Glibert, P. M. and Bronk, D. A.: Release of dissolved organic nitrogen by marine diazotrophic cyanobacteria, Trichodesmium spp., Appl. Environm. Microbiol., 60, 3996-4000, 1994.

Glibert P. M. and O'Neil, J. M.: Dissolved organic nitrogen release and amino acid oxidase activity by Trichodesmium spp., Bull Inst. Océanogr. Monaco, 19, 265-271, 1999.

Gruber, N. and Sarmiento, J.: Global patterns of marine nitrogen fixation and denitrification, Global Biogeochem. Cycles, 11, 235-266, 1997.

Hansell, D. A. and Carlson, C. A.: Biogeochemistry of total organic carbon and nitrogen in the Sargasso Sea: control by convective overturn, Deep-Sea Res. II, 48, 1649-1667, 2001.

Hawser, S. P. and Codd, G. A.: The toxicity of Trichodesmium blooms from Caribbean waters, pp. 319-329, in: Marine Pelagic Cyanobacteria: Trichodesmium and other Diazotrophs, edited by: Carpenter, E. J., Capone, D. G., and Rueter, J. G., Kluwer Academic Publishers, 1992.

Hewson, I., Govil, S. R., Capone, D. G., Carpenter, E. J., and Fuhrman, J. A.: Evidence of Trichodesmium viral lysis and potential significance for biogeochemical cycling in the oligotrophic ocean, Aquatic Microbial Ecol., 36, 1-8, 2004.

Hood, R. R., Michaels, A. F., and Capone, D. G.: Answers sought to the enigma of marine nitrogen fixation, EOS, Transactions, American Geophysical Union, 81, 133, 138-139, 2000.

Hood, R. R., Bates, N. R., Capone, D. G., and Olson, D. B.: Modeling seasonal and interannual biogeochemical and $\mathrm{N}_{2}$ fixation cycles at BATS, Deep-Sea Res. Part II, 48, 1609-1648, 2001.

Hood, R. R., Coles, V. J., and Capone, D. G.: Modeling the distribution of Trichodesmium and nitrogen fixation in the Atlantic Ocean. J. Geophys. Res. 109, C06006, doi:10.1029/2002JC001753, 2004.

Hutchins, D. A., Fu, F.-X., Zhang, Y., Warner, M. E., Feng, Y., Portune, K., Bernhardt, P. W., and Mulholland, M. R.: $\mathrm{CO}_{2}$ control of Trichodesmium $\mathrm{N}_{2}$ fixation, photosynthesis, growth rates and elemental ratios: Implications for past, present and future ocean biogeochemistry, Limnol. Oceanogr., accepted, 2007.

Kana, T. M.: Oxygen cycling in cyanobacteria with specific reference to oxygen protection in Trichodesmium spp., p. 29-41, in: Marine Pelagic Cyanobacteria: Trichodesmium and other Diazotrophs, edited by: Carpenter, E. J., Capone, D. G., and Rueter, J. G., Kluwer Academic Publishers, 1992.

Kana, T. M.: Rapid oxygen cycling in Trichodesmium thiebautii, Limnol. Oceanogr., 38, 18-24, 1993.

Karl, D. M., Letelier, R., Hebel, D. V., Bird, D. F., and Winn, C. D.: Trichodesmium blooms and new nitrogen in the North Pacific Gyre, p. 219-237, in: Marine Pelagic Cyanobacteria: Trichodesmium and other Diazotrophs, edited by: Carpenter, E. J., Capone, D. G., and Rueter, J. G., Kluwer Academic Publishers, 1992.

Karl, D., Michaels, A., Bergman, B., Capone, D., Carpenter, E., Letelier, R., Lipschultz, F., Paerl, H., Sigman, D., and Stal, L.: 
Nitrogen fixation in the world's oceans, Biogeochemistry, 57/58, 47-98, 2002.

Karl, D. M., Letelier, R., Hebel, D., Tupas, L., Dore, J., Christian, J., and Winn, C.: Ecosystem changes in the North Pacific subtropical gyre attributed to the 1991-1992 El Nino, Nature, 373, 230-234, 1995.

Karl, D. M., Letelier, R., Tupas, L., Dore, J., Christian, J., and Hebel, D.: The role of nitrogen fixation in biogeochemical cycling in the subtropical North Pacific, Nature, 388, 533-538, 1997.

Knapp, A. N., Sigman, D. M., and Lipschultz, F.: N isotopic composition of dissolved organic nitrogen and nitrate at the Bermuda Atlantic Time-series Study site, Global Biogeochem. Cycles, 19, GB1018, doi:10.1029/2004GB002320, 2005.

Kromkamp, J., de Bie, M., Goosen, N., Peen, J., Van Rijswijk, P., Sinke, J., and Duineveld, G. C. A.: Primary production by phytoplankton along the Kenyan coast during the SE monsoon and November intermonsoon 1992, and the occurrence of Trichodesmium, Deep-Sea Res. II, 44, 1195-1212, 1997.

LaRoche, J. and Breitbarth, E.: Importance of the diazotrophs as a source of new nitrogen in the ocean, Netherlands J. Sea Res., 53, 67-91, 2005.

Lenes, J. M., Darrow, B. P., Cattrall, C., Heil, C. A., Callahan, M., Vargo, G. A., Byrne, R. H., Prospero, J. M., Bates, D. E., and Walsh, J. J.: Iron fertilization and the Trichodesmium response on the West Florida shelf, Limnol. Oceanogr., 46, 1261-1277, 2001

Letelier, R. M. and Karl, D. M.: Role of Trichodemsium spp. in the productivity of the subtropical North Pacific Ocean, Mar. Ecol., Prog. Ser., 133, 263-273, 1996.

Li, W. K. W., Glover, H. E., and Morris, I.: Physiology of carbon photoassimilation by Oscillatoria theiebautii in the Caribbean Sea, Limnol. Oceanogr., 25, 447-456, 1980.

Lomas, M. W. and Glibert, P. M.: Temperature regulation of nitrate uptake: a novel hypothesis about nitrate uptake and reduction in cool-water diatoms, Limnol. Oceanogr., 44, 556-572, 1999.

Lomas, M. W., Rumbley, C. J., and Glibert, P. M.: Ammonium release by nitrogen sufficient diatoms in response to rapid increases in irradiance, J. Plankton Res., 22, 2351-2366, 2000.

Lugomela, C., Lyimo, T. J., Bryceson, I., Semesi, A. K., and Bergman, B.: Trichodesmium in coastal waters of Tanzania: diversity, seasonality, nitrogen and carbon fixation, Hydrobiologia, 477, 1-13, 2002.

Mague, T. H., Weare, N. M., and Holm-Hansen, O.: Nitrogen fixation in the North Pacific Ocean, Mar. Biol., 24, 109-119, 1974.

Mague, T. H., Mague, F. C., and Holm-Hansen, O.: Physiology and chemical composition of nitrogen-fixing phytoplankton in the central North Pacific Ocean, Mar. Biol., 41, 213-227, 1977.

Mahaffey, C., Michaels, A., and Capone, D. G.: The conundrum of marine nitrogen fixation, Am. J. Sci., 305, 546-595, 2005.

McCarthy, J. J. and Carpenter, E. J.: Oscillatoria (Trichodesmium) thiebautii (Cynaophyta) in the central North Atlantic Ocean, J. Phycol., 15, 75-82, 1979.

Michaels, A. F., Olson, D., Sarmiento, J. L., Ammerman, J. W., Fanning, K., Jahnke, R., Knap, A. H., Lipschultz, F., and Prospero, J. M.: Inputs, losses and transformations of nitrogen and phosphorous in the pelagic North Atlantic Ocean, Biogeochemistry, 35, 181-226, 1996.

Mills, M. M., Ridame, C., Davey, M., LaRoche, J., and Geider, R.
J.: Iron and phosphorus co-limit nitrogen fixation in the eastern tropical North Atlantic, Nature, 429, 292-294, 2004.

Montoya, J. P., Voss, M., Kähler, P., and Capone, D. G.: A simple, high precision tracer assay for dinitrogen fixation, Appl. Environ. Microbiol., 62, 986-993, 1996.

Montoya, J. P., Carpenter, E. J., and Capone, D. G.: Nitrogen fixation and isotope abundance in zooplankton of the oligotrophic North Atlantic, Limnol. Oceanogr., 47, 1617-1628, 2002.

Montoya, J. P., Holl, C. M., Zehr, J. P., Hansen, A., Villareal, T. A., and Capone, D. G.: High rates of $\mathrm{N}_{2}$ fixation by unicellular diazotrophs in the oligotrophic Pacific Ocean, Nature, 430, 1027-1032, 2004.

Mulholland, M. R. and Bernhardt, P. W.: The effect of growth rate, phosphorus concentration and temperature on $\mathrm{N}_{2}$ fixation and $\mathrm{N}$ regeneration rates in continuous cultures of Trichodesmium IMS101, Limnol. Oceanogr., 50, 839-849, 2005.

Mulholland, M. R., Bernhardt, P. W., Heil, C. A., Bronk, D. A., and O'Neil, J. M.: Nitrogen fixation and regeneration in the Gulf of Mexico, Limnol. Oceanogr., 51, 176-177, 2006.

Mulholland, M. R., Bronk, D. A., and Capone, D. G.: $\mathrm{N}_{2}$ fixation and regeneration of $\mathrm{NH}_{4}^{+}$and dissolved organic $\mathrm{N}$ by Trichodesmium IMS101, Aquatic Microb. Ecol., 37, 85-94, 2004a.

Mulholland, M. R. and Capone, D. G.: Nitrogen utilization and metabolism relative to patterns of $\mathrm{N}_{2}$ fixation in populations of Trichodesmium from the North Atlantic Ocean and Caribbean Sea, Mar. Ecol. Prog. Ser., 188, 33-49, 1999.

Mulholland, M. R. and Capone, D. G.: The physiology of the marine $\mathrm{N}_{2}$ fixing cyanobacteria Trichodesmium, Trends in Plant Science, 5, 148-153, 2000.

Mulholland, M. R. and Capone, D. G.: The stoichiometry of N and $\mathrm{C}$ utilization in cultured populations of Trichodesmium IMS101, Limnol. Oceanogr., 46, 436-443, 2001.

Mulholland, M. R., Glibert, P. M., Berg, G. M., Van Heukelem, L., Pantoja, S., and Lee, C.: Extracellular amino acid oxidation by phytoplankton and cyanobacteria: a cross-ecosystem comparison, Aquat. Microb. Ecol., 15, 141-152, 1998.

Mulholland, M. R., Heil, C. A., Bronk, D. A., O’Neil, J. M., and Bernhardt, P. W.: Does nitrogen regeneration from the $\mathrm{N}_{2}$ fixing cyanobacteria, Trichodesmium spp. fuel Karenia brevis blooms in the Gulf of Mexico?, p. 47-49, in: Harmful Algae 2002, edited by: Steidinger, K. A., Lansberg, J. H., Tomas, C. R., and Vargo, G. A., Florida Fish and Wildlife Conservation Commission, Florida Institute of Oceanography, and Intergovernmental Oceanographic Commission of UNESCO, St. Petersberg, Florida, USA, 2004b.

Mulholland, M. R., Ohki, K., and Capone, D. G.: Nitrogen utilization and metabolism relative to patterns of $\mathrm{N}_{2}$ fixation cultures of Trichodesmium NIBB1067, J. Phycol., 35, 977-988, 1999a.

Mulholland, M. R., Ohki, K., and Capone, D. G.: Nutrient controls on nitrogen uptake and metabolism by natural populations and cultures of Trichodesmium (Cyanobacteria), J. Phycol., 37, 1001-1009, 2001

Mulholland, M. R., Shoemaker, C., Ohki, K., and Capone, D. G.: Utilization of combined forms of $\mathrm{N}$ in cultures and field populations of Trichodesmium, Bull. Inst. Océanogr. Monaco, 19, 279-286, 1999b.

Nausch, M.: Microbial activities on Trichodesmium colonies, Mar. Ecol. Prog. Ser., 141, 173-181, 1996.

Ohki, K.: A possible role of temperate phage in the regulation 
of Trichodesmium, Bull. Inst. Oceanogr. Monaco, 19, 235-256, 1999.

Ohlendieck, U., Stuhr, A., and Siegmund, H.: Nitrogen fixation by diazotrophic cyanobacteria in the Baltic Sea and transfer of the newly fixed nitrogen to picoplankton organisms, J. Mar. Syst., 25, 213-219, 2000.

O'Neil, J. M.: The colonial cyanobacterium Trichodesmium as a physical and nutritional substrate for the harpacticoid copepod Macrosetella gracilis, J. Plank. Res., 20, 43-59, 1998.

O'Neil, J. M.: Grazer interactions with nitrogen-fixing marine Cyanobacteria: adaptation for $\mathrm{N}$-acquisition?, Bull. Inst. Oceanogr. Monaco, 19, 293-317, 1999.

O'Neil, J. M., Metzler, P., and Glibert, P. M.: Ingestion of ${ }^{15} \mathrm{~N}_{2}$ labelled Trichodesmium, and ammonium regeneration by the pelagic harpacticoid copepod Macrosetella gracilis, Mar. Biol., 125, 89-96, 1996.

O-Neil, J. M. and Roman, M. R.: Ingestion of the cyanobacterium Trichodesmium spp. by the pelagic harpacticoid copepods Macrosetella, Miracia and Oculosetella, Hydrobiologia, 292293, 235-240, 1994.

Orcutt, K. M., Lipschultz, F., Gundersen, K., Arimoto, R., Michaels, A. F., Knap, A. H., and Gallon, J. R.: A seasonal study of the significance of $\mathrm{N}_{2}$ fixation by Trichodesmiuim spp. at the Bermuda Atlantic Time-series Study (BATS) site, Deep-Sea Res. II, 48, 1583-1608, 2001.

Paerl, H. W. and Bebout, B. M.: Direct measurement of $\mathrm{O}_{2-}$ depleted microzones in marine Oscillatoria: relation to $\mathrm{N}_{2}$ fixation, Science, 241, 442-445, 1988.

Paerl, H. W., Bebout, B. M., and Prufert, L. E.: Bacterial associations with marine Oscillatoria sp. (Trichodesmium sp.) populations: ecophysiological implications, J. Phycol., 25, 773-784, 1989.

Renaud, F., Pringault, O., and Rochelle-Newall, E.: Effects of the colonial cyanobacterium Trichodesmium spp. on bacterial activity, Aquatic Microbial Ecol., 41, 261-270, 2005.

Renström-Kellner, E., Rai, A. N., and Bergman, B.: Glycolate metabolism in cyanobacteria II. Evidence for a mediated transport of glycolate in Anabaena, Physiol. Plant., 75, 144-150, 1989.

Revelante, N., Williams, W. T., and Bunt, J. S.: Temporal and spatial distribution of diatoms, dinoflagellates and Trichodesmium in waters of the Great Barrier Reef, J. Exp. Mar. Biol. Ecol., 63, 27-45, 1982.

Roman, M. R.: Ingestion of the blue-green alga Trichodesmium by the harpacticoid copepod Macrosetella gracilis, Limnol. Oceanogr., 23, 1245-1248, 1978.

Romans, K. M., Carpenter, E. J., and Bergman, B.: Buoyancy regulation in the colonial diazotrophic cyanobacterium Trichodesmium tenue: ultrastructure and storage of carbohydrate, polyphosphate and nitrogen, J. Phycol., 30, 935-942, 1994.

Saino, T.: Biological nitrogen fixation in the ocean with emphasis on the nitrogen fixing blue-green alga Trichodesmium and its significance in the nitrogen cycling in the low latitude sea areas, PhD Thesis, Ocean Research Institute, University of Tokyo, 1977.

Saino, T. and Hattori, A.: Diel variation in nitrogen fixation by a marine blue-green alga, Trichodesmium thiebautii, Deep-Sea Res., 25, 1259-1263, 1978.

Saino, T. and Hattori, A.: Nitrogen fixation by Trichodesmium and its significance in nitrogen cycling in the Kuroshio area and adjacent waters, p. 697-709, in: The Kuroshio IV, edited by: Takenouti, A. Y., Saikon Publishing, 1980.

Sañudo-Wilhelmy, S. A., Kustka, A. B., Gobler, C. J., Hutchins, D. A., Yang, M., Lwiza, K., Burns, J., Capone, D. G., Raven, J. A., and Carpenter, E. J.: Phosphorus limitation of nitrogen fixation by Trichodesmium in the central North Atlantic Ocean, Nature, 411, 66-69, 2001

Scranton, M. I.: The role of the cyanobacterium Oscillatoria (Trichodesmium) thiebautii in the marine hydrogen cycle, Mar. Ecol. Prog. Ser., 11, 79-87, 1983.

Scranton, M. I.: Hydrogen cycling in the waters near Bermuda: the role of the nitrogen fixer, Oscillatoria thiebautii, Deep-Sea Res., 31, 133-143, 1984.

Scranton, M. I., Novelli, P. C., Michaels, A., Horrigan, S. G., and Carpenter, E. J.: Hydrogen production and nitrogen fixation by Oscillatoria thiebautii during in situ incubations, Limnol. Oceanogr., 32, 998-1006, 1987.

Sellner, K. G.: Trophodynamics of marine cyanobacteria blooms, p. 75-94, in: Marine Pelagic Cyanobacteria: Trichodesmium and other Diazotrophs, edited by: Carpenter, E. J., Capone, D. G., and Rueter, J. G., Kluwer Academic Publisher, 1992.

Sellner, K. G.: Physiology, ecology, and toxic properties of marine cyanobacteria blooms, Limnol. Oceanogr., 42, 1089-1104, 1997.

Sheridan, C. C., Steinberg, D. K., and Kling, G. W.: The microbial and metazoan community associated with colonies of Trichodesmium spp.: a quantitative survey, J. Plank. Res., 24, 913-922, 2002.

Shimura, S., Yamaguchi, T., Aruga, Y., Fujita, Y., and Ichimura, S.: Extracellular release of photosynthetic products by a pelagic blue green alga Trichodesmium thiebautii, J. Oceanogr. Soc. Japan, 34, 181-188, 1978.

Sieburth, J. McN. and Conover, J. T.: Slicks associated with Trichodesmium blooms in the Sargasso Sea, Nature, 205, 830-831, 1965.

Siddiqui, P. J. A., Bergman, B., and Carpenter, E. J.: Filamentous cyanobacterial associates of the marine planktonic cyanobacterium Trichodesmium, Phycologia, 31, 326-337, 1992.

Stal, L. J.: Tansley Review No. 84. Physiological Ecology of Cyanobacteria in Microbial Mats and Other Communities, New Phytologist, 131, 1-32, 1995.

Steinberg, D. K., Nelson, N. B., Carlson, C. A., and Prusak, A. C.: Production of chromophoric dissolved organic matter (CDOM) in the open ocean by zooplankton and the colonial cyanobacterium Trichodesmium spp., Mar. Ecol. Prog. Ser., 267, 45-56, 2004.

Subramaniam, A., Carpenter, E. J., Karentz, D., and Falkowski, P. G.: Bio-Optical Properties of the Marine Diazotrophic Cyanobacteria Trichodesmium spp. I. Absorption and Photosynthetic Action Spectra, Limnol. Oceanogr., 44, 608-617, 1999.

Tseng, Y.-F., Lin, F.-J., Chiang, K.-P., Kao, S.-J., and Shiah, F.K.: Potential impacts of the $\mathrm{N}_{2}$-fixing Trichodesmium on heterotrophic bacterioplankton turnover rates and organic carbon transfer efficiency in the subtropical oligotrophic ocean system, Terrestrial, Atmospheric and Ocean Sciences, 16, 361-376, 2005.

Villareal, T. A. and Carpenter, E. J.: Diel buoyancy regulation in the marine diazotrophic cyanobacterium Trichodesmium thiebautii Ehr, Limnol. Oceanogr., 35, 1832-1837, 1990. 
Voss, M., Croot, P., Lochte, K., Mills, M., and Peeken, I.: Patterns of nitrogen fixation along $10^{\circ} \mathrm{N}$ in the tropical Atlantic, Geophys. Res. Lett., 31, L23S09, doi:10.1029/2004GL020127, 2004.

Walsby, A. E.: The gas vesicles and buoyancy of Trichodesmium, p. 141-161, in: Marine Pelagic Cyanobacteria: Trichodesmium and other Diazotrophs, edited by: Carpenter, E. J., Capone, D. G., and Rueter, J. G., Kluwer Academic Publishers, 1992.
Walsh, J. J. and Steidinger, K. A.: Saharan dust and red tides: the cyanophyte connection, J. Geophys. Res., 106, 11 597-11612, 2001.

Zehr, J. P., Waterbury, J. B., Turner, P. J., Montoya, J. P., Omoregie, E., Steward, G. F., Hansen, A., and Karl, D. M.: Unicellular cyanobacteria fix $\mathrm{N}_{2}$ in the subtropical North Pacific Ocean, Nature, 412, 635-638, 2001. 